JERZY WISLOCKI

\title{
Źródla elektroniczne - nowe możliwości badawcze
}

\section{Elektronische Quellen - neue Forschungsmöglichkeiten}

Chciałbym zwrócić uwage historyków państwa i prawa polskiego na nowe możliwości badawcze, które otwiera dysk kompaktowy Teki Dworzaczka. Dysk pod tym tytułem opublikowaliśmy w serii wydawnictw Biblioteki Kórnickiej PAN w 1995 r., jako efekt zrealizowanego projektu badawczego, finansowanego przez Komitet Badań Naukowych. Było to wydarzenie bez precedensu w naukach historycznych.

W $1988 \mathrm{r}$. od prof. Wlodzimierza Dworzaczka, wybitnego polskiego historyka i genealoga, pozyskałem do zbiorów Biblioteki Kórnickiej PAN wypisy źródłowe, które gromadzil przez blisko 40 lat, do zamierzonej publikacji herbarza wielkopolskiej szlachty. Część tego herbarza była opracowana $\mathrm{w}$ maszynopisie (ok. $25 \%$ ), natomiast podstawowy materiał był zgromadzony w formie około 300000 regestów. Ze względu na kwalifikacje autora nikt nie miał wątpliwości, że są to regesty najwyższej próby, zasługujące na pelne zaufanie, ale dalsze ich wykorzystywanie było prawie niemożliwe. Regesty były sporządzane ręcznie, na kartach A4, sukcesywnie - w trakcie wykorzystywania przez Autora wielkopolskich ksiąg sądowych ziemskich i grodzkich $\mathrm{z}$ XV do XVIII w. oraz akt metrykalnych i prasy XVIII i XIX w. Pisząc herbarz, Autor ustawicznie musial wertować kilka tysięcy zapisanych stron, aby wyłuskać potrzebne $\mathrm{Mu}$ informacje. Kontynuowanie Jego dziela $\mathrm{w}$ tradycyjnej formie wydawało się być niemożliwe. Zaradzić temu mogła tylko komputeryzacja zbiorów.

Wkrótce dysk ten zaczął być wykorzystywany $w$ wielu uczelniach, ale głównie jako pomoc $w$ edukacji studentów historii $w$ posługiwaniu się techniką komputerową, natomiast dużą popularność zdobył wśród amatorów genealogii w Polsce i USA. Dysk jednak został potraktowany przede

\footnotetext{
' Szczególowy opis całego zbioru zob. na dysku lub: Jerzy Wisłocki, Adam Bieniaszewski, Rafał Prinke, Spuścizna Wlodzimierza Dworzaczka, Pamiętnik Biblioteki Kórnickiej 1996, z. 24 , s. $169-182$.
} 
wszystkim jako zbiór materiałów źródłowych do genealogii polskiej szlachty $z$ dużą szkodą dla zawartych $w$ nim innych materiałów.

Prof. Włodzimierz Dworzaczek rzeczywiście zbieral materiały do herbarza wielkopolskiej szlachty, ale jeśli $w$ trakcie lektury natknąl się na rozmaite inne informacje, odnotowywał je. Trzeba jedynie próbować do nich dotrzeć i tym chcialbym zainteresować historyków prawa.

Każdy regest zawiera nazwiska $\mathrm{i}$ imiona od dwóch do kilkunastu osób występujących przed sądem grodzkim bądź ziemskim w sprawach cywilnych: spornych $\mathrm{i}$ niespornych oraz karnych. W regestach jest opisany rodzaj sprawy, nazwa dóbr, jeśli one były przedmiotem postępowania, wysokość nawiązek w sprawach karnych itp. Regesty mają podobną strukturę:

1211 (Nr. 1113 IV) 1687

Joanna ze Skrzypny Twardowska wd. po Rafale Objezierskim żupniku bydg., w im. sw. i synów swych: Zygmunta i Antoniego Objezierskich, Ocieszyno i Gołembowo w pow. poznań. Janowi Albrachtowi Cieleckiemu s. o. Bolesława C. za 40.000 złp. sprzedają (f. 42).

946 (Nr. 172) 1647

Jan Wład. Wolski sędzia gr. piotrk. 1646. Zygm. Oleski i Anna Przerębska małż, on wsi Oleśnice Kamionki tak po + ojca ol. Mikołaja O. spadłych, jak i od br. rodz. Lukasza Oktawjana $O$. nabytych dziedzic, ona pani wienna i dożyw., pw. Lukaszowi Oktawjanowi O. $\mathrm{i}$ innym o zajazd. tych dóbr. Łukasz-Oktaw. đożywotnik ol. żony swej Zofji Waierówny, w im. sw. i dzieci z niej spłodz. wieś tę sprzedal za 17. 666 złp. aktorowi (f. 127).

Regesty dają możliwość badania form obrotu nieruchomościami (sprzedaż, zastaw, dzierżawa, wiano, oprawa itp.) i ich wartości. Przeszukując zbiory pod hasłem miejscowości, można łatwo sprawdzić, jak często dobra szlacheckie zmieniały właścicieli, jakie były zasady spadkobrania itd. Badania takie można przeprowadzać w ustalonych okresach chronologicznych. Autor bardzo skrupulatnie odnotowywał też tytuły uczestników transakcji, operując skrótami: N - nobilis, G - generosus, MD - magnificus dominus, ill. - illustris, co ulatwia ustalenie statusu spolecznego stron.

Przeszukując zbiór pod np. poszukiwanymi hasłami: zajazd, zabór, napad, zabójstwo, morderstwo, glowa (glówszczyzna) itp., komputer wyłowi rozmaite wydarzenia:

\section{$819(\mathrm{Nr} 196) 1669$}

Adam Lukomski, s. o. Wawrzyńca L. z Krystyny Koszutskiej w im. sw. oraz Katarzyny ż. Stanisł. Bogusławskiego, i Barbary Ł. Ł. sióstr swych rodzonych, pw. Serafinowi Lipnickiemu i Helenie Bronikowskiej małz. i ich wspólnikom, o zajęcie 1/2 wsi Stawu, protestantów posesji (f. 235v) W czasie zajazdu i oblęż. dworu była w nim i N. Kat. Pokubiatowska

$1349(\mathrm{Nr} 128) 1597$

Agnieszka z Złotków wdowa po ol. Wojc. Rydzyńskim, pw. Janowi Pogorzelskiemu, s. o. Jakuba Pogorzel. $z$ Zawor, o to iż gdy aktorka wracała $z$ pogrzebu brata ol. Jakuba 
Grabskiego $\mathrm{z}$ m. Stawiszyna w roku ubiegłym z córką, napadł ją w Jaraczewie i więził w swym dworze w Zaworach, chcąc zmusić do małż. zabrał ją stamtąd Stanisł. Pogorzelski, podsędek i surrog. kaliski i oddal jej bratu rodz. Stanisławowi Zlotkowskiemu (f. 46)

\section{$1148(\mathrm{Nr} 9) 1546$}

1539. Wizja głowy zabitej ol. Wojciecha Koryckiego we dworze Jadwigi K. wd. po ol. Walentynie Tomickim we wsi Koryta. Zabity w czasie zbrojnego zajazdu jej domu przez G. Stanisł. Rozdrażewskiego, (f. 221). Wtedy też zabity przez R. i otoczenie jego ol. Jakub Trczieński, o co protest, jego brat stryj. rodzony Jerzy T. (f. 221v). panna Katarzyna Korycka, siostra rodz. zabitego ol. Wojc. K. (f. ib.)

\section{$2701(\mathrm{Nr} 182 \mathrm{~A}) 1658$}

Marjanna Ulanowska, wdowa po ol. Piotrze Malczewskim zamordowanym, w im. sw. oraz Barbary i Konstancji z ol. Katarzyny Biernackiej 1-o v. zrodz., oraz Antoniego, Jadwigi i Zofji ze sobą zrodz. 2-o v. dzieci, małoletnich, pw Aleksandrowi Karłowskiemu pierwszemu zabójcy i sługom jego; w sobotę przed Niedz. Palm. w Ostrowie wsi dziedz. M-go, zbrojny zajazd i morderstwo (f. 66). Kazimierz M. brat rodz. ol. Piotra (f. 67)

Trudniejsze są badania nad piastowaniem urzędów, ale i w tym przypadku regesty stanowią nieocenioną pomoc. Urzędy były uzyskiwane stopniowo, zgodnie z ich znaczeniem, ale także z pominięciem ich hierarchii. Stosunkowo latwe jest ustalenie przyczyn takich awansów - analizując powiązania genealogiczne. Możemy się przekonać, jak najwyższe urzędy ziemskie przechodziły $z$ ojca na syna, a $w$ braku męskiego potomka - przez córkę na zięcia. Są to tylko niektóre przykłady możliwości badawczych, jakie dają Teki Dworzaczka.

Zachęcony uzyskanymi rezultatami, postanowiłem utworzyć samodzielną jednostkę organizacyjną z zadaniem popularyzacji osiągnięć nauki zachodnioeuropejskiej w elektronizacji źródeł oraz przystosowywania ich do polskich żródeł historycznych. Zorganizowaliśmy Centrum Elektronicznych Tekstów Humanistycznych, z czterema stanowiskami pracy, finansowane przez Komitet Badań Naukowych. Rezultaty prac są zachęcające ${ }^{2}$, ale jednocześnie wskazują na to, że bez dalszego finansowania komputeryzacji źródeł historycznych w Poisce trudno będzie osiągnąc znaczące wyniki.

W Polsce $w$ badaniach historycznych komputerami posługują się środowiska w Białymstoku, Olsztynie, Warszawie i Krakowie, ale niemal wyłącznie w zakresie historii gospodarczej i demografii historycznej. W rezultacie tworzą się zespoły, dla których podstawową pomocą w badaniach są bazy danych, a więc źródła w przetworzonej postaci, która nie ma odpowiednika w tradycyjnej metodzie publikacji źródeł. W Centrum podjęliśmy próby komputeryzacji źródeł typu narracyjnego, nie rezygnując $\mathrm{z}$ tworzenia baz danych. Wyniki tych prób zostały opublikowane na internetowej stronie

${ }^{2}$ Efektem działalności Centrum jest monografia: Rafał T. Prinke, Fontes ex machina. Model komputerowej analizy źródel historycznych, Poznań 2000, ss. 342. 
Biblioteki Kórnickiej (bkpan.poznan.pl). Można tam znaleźć: dwie bazy danych (1. Genealogia wielkopolskiej szlachty, 2. Katalog starych druków Biblioteki Kórnickiej PAN), publikację zbiorową Nuntius vetustatis oraz dwa diariusze sejmowe $z$ lat 1764 i 1793.

Prowadzone $\mathrm{w}$ Centrum prace pozwolily na opracowanie koncepcji dysku tematycznego pod haslem Elity polityczne I Rzeczypospolitej. Źródla $i$ materialy. Jest to propozycja gromadzenia na jednym dysku materiałów, które mogą być podstawą do pogłębionych badań nad aktywnością polityczną szlachty, ich mentalnością, powiązaniami rodowymi, zasadami dzierżenia urzędów itd. Struktura dysku będzie przedstawiała się następująco:

I. Król

a. Genealogie dynastyczne:

- Oswald Balzer, Genealogia Piastów, Kraków 1895

- Włodzimierz Dworzaczek, Genealogia. Tablice, Warszawa 1959

- Kazimierz Jasiński, Rodowód pierwszych Piastów, Wrocław [1992]; Rodowód Piastów Ślqzskich, t. 1-3, Wroclaw 1973-1977; Rodowód Piastów Mazowieckich, Wrocław [w druku]

- Edward Rymar, Rodowód ksiqżąt pomorskich, t. 1-2, Szczecin 1995

- Zygmunt Wdowiszewski, Genealogia Jagiellonów, Warszawa 1968

- Józef Wolf, Kniaziowie litewsko-ruscy od końca czternastego wieku, Warszawa 1895

b. Ikonografia królów polskich

c. Polska heraldyka królewska

II. Parlament
a. Diariusze sejmowe
b. Volumina legum
c. Akta sejmikowe

III. Urzędnicy
a. Baza danych urzędników staropolskich
b. Podziały administracyjne
c. Urzędy w rozwoju dziejowym

\section{Szlachta}

a. Genealogiczna baza danych: Szlachta polska $X V-X V I I I$ w.

b. Herbarze:

- Bartosz Paprocki, Herby rycerstwa polskiego, Krakow 1584

- Kasper Niesiecki, Herbarz polski, t. 1-10, wyd. J. N. Bobrowicz, Lipsk 1839-1846

- Teodor Żychliński, Zlota ksiega szlachty polskiej, t. 1-31, Poznań 1879-1908

- Adam Boniecki, Herbarz Polski, t. 1-16, Warszawa 1899-1913

- Seweryn Uruski, Rodzina. Herbarz szlachty polskiej, t. 1-15, Warszawa 1905-1938

c. Biografie:

- Polski Słownik Biograficzny

- Pamięlniki

d. Źródła:

- Teki Dworzaczka

- Teki Łempickiego

- Teki Luszczyńskiego 
Tak zaprojektowany dysk jest sukcesywnie realizowany. Do opublikowanych Tek Dworzaczka dotyczących genealogii szlachty wielkopolskiej dodamy materiały do genealogii szlachty mazowieckiej (Teki Lempickiego) oraz genealogii szlachty województwa krakowskiego (Teki Euszczyńskiego) - prace zostaną zakończone w 2000 r. Trwaja przygotowania do utworzenia bazy danych Urzednicy staropolscy oraz Szlachta polska XV-XVIII $w$. Zakończona zostala edycja dwóch diariuszy sejmowych z lat 1764 i 1793. Metodą skanowania przygotowano do publikacji diariusze $z$ lat 1750, 1752, 1754, 1758, wydane przez Wladysława Konopczyńskiego, a trwają prace nad kopiowaniem diariusza Sejmu Wielkiego.

Różnorodne materiały, które zostaną umieszczone na projektowanym dysku, dały podstawę do prezentowania rozmaitych technik elektronicznej edycji źródel. Będą tam zamieszczone bazy danych, ale także teksty źródeł narracyjnych, jak na przykład diariusze sejmowe kopiowane $\mathrm{z}$ rękopisów $w$ wersji transliterowanej (diariusz z 1764 r.), modernizowanej (diariusz z 1793 r.) bądź skanowanej z tekstów już opublikowanych (diariusze z publikacji W. Konopczyńskiego). Takie postępowanie daje możliwość podjęcia w przyszłości dyskusji nad najdogodniejszą formą elektronicznej publikacji źródel historycznych.

Podstawowym jednak celem dysku jest dostarczenie historykom materiałów do badań elit politycznych. Do nich niewątpliwie zalicza się szlachta. Założeniem ideowym jest umożliwienie zbadania, jak przedstawiały się kariery posłów szlacheckich. Po wyborze posła na sejmiku będzie można ustalić jego dane osobowe, wypowiedzi na sejmiku przedsejmowym, w sejmie, na sejmiku relacyjnym, piastowane urzędy przed wyborami i po zakończeniu misji poselskiej, przyrost majątku, koneksje genealogiczne, poziom wyksztalcenia, a także - w ograniczonym zakresie - mentalność. Można przecież, wykorzystując diariusze sejmowe, podjąć próbę odpowiedzi na pytanie, jak były przez posłów postrzegane narody ościenne, jakie panowały stereotypy, jak oceniano politykę zagraniczna, itd. A do tego nie trzeba wertować całego diariusza (diariusz sejmu z 1793 r. zawiera 1200 stron maszynopisu), lecz można wyręczyć się komputerem.

Realizacja takiego dysku wymaga jednak wspólpracy wielu wykonawców, szczególowych zadań i konieczna będzie koordynacja prac w skali calego kraju. Ale już obecnie historycy powinni posiąść umiejętności wykorzystywania do badań elektronicznie przetworzonych tekstów źródłowych. 